Original article

\title{
Individual and parental factors on depressive disorder and its detrimental effects among adolescents and young adults: A study from Bihar state, India
}

\author{
Tanu Das ${ }^{\text {a, }}$, Partha Das ${ }^{\text {a }}$, Prabir Kumar Kundu ${ }^{\text {b }}$, Tamal Basu Roy ${ }^{\text {a, }}$ \\ ${ }^{a}$ Department of Geography, Raiganj University, Uttar Dinajpur, West Bengal, India \\ ${ }^{\mathrm{b}}$ Department of Geography, Siliguri Mahila Mahavidyalaya, West Bengal, India
}

\section{A R T I C L E I N F O}

\section{Keywords:}

Depression

Adolescents

Adult

Mental health

UDAYA

Bihar

\begin{abstract}
A B S T R A C T
Introduction: Worldwide depression is one of the most common chronic disorder as well as mental health problems in adolescent and young adult boys \& girls. In Bihar, as per the report published by population council of India namely "Understanding the lives of adolescents and young adults (UDAYA) in Bihar, India", pointed out that more than $90 \%$ boys \& girls exposed their symptoms of mildly depressive disorders and nearly $15 \%$ boys and girls reported their symptom of moderate to severe depressive disorders.

Objectives: This current study identified the risk factors of moderate to severe depressive disorders among adolescents and young adults from Bihar, a most underdeveloped state of India. This study also to identify is there any relationship between depressive disorders and educational outcome as well as suicidal outcome of adolescents and young adults in Bihar.

Methodology adopted: Descriptive statistics, Logistic regression and Chi-square test were adopted to complete this study.

Results: The likelihood of moderate to severe depressive disorder is higher among to those adolescents or young adults who were physically punished [AOR: 1.59; P $<0.05$; 95\% CI: 1.48-1.71] by their parent, had no permission to disclose their opinion to the other elder member of that family [AOR: $1.41 ; \mathrm{P}<0.05 ; 95 \% \mathrm{CI}$ : 1.12-1.57] and to those whose parents neglect their child to hear personal things [AOR: 1.18; P $<0.05 ; 95 \% \mathrm{CI}$ : 0.96-1.31] if they want to share, studied at private school and whose mother had no educational attainment or very less.
\end{abstract}

\section{Introduction}

Worldwide depression is one of the most common chronic disorders as well as mental health problems in adolescent and young adult boys \& girls. Adolescence is the transitional phase from childhood to adulthood and is marked by emotional fluidity along with rigorous physical and social changes that can be some leading causes of emotional misbalance, anxiety and depressive disorders. Former studies indicated that childhood anxiety is associated with adulthood depression for both men \& women. ${ }^{1}$ Numerous previous pieces of literature have documented that adolescents and adult's depression is significantly associated with a series of sluggish outcomes, including academic failure, increased risk of suicide, impairment in cognitive \& social functioning and greater self-neglect, insomnia, addictiveness, substance abuse etc. ${ }^{2-5}$ All of these are in turn associated with increased risk of morbidity and mortality. ${ }^{6-10}$ Following the World Health Organization (WHO), depression will be one of the most leading causes of global diseases by $2030 .{ }^{11,12}$ Worldwide, an estimate accounted that currently, the total number of people living with depression is 322 million and nearly half of these people live in South-East Asia \& Western Pacific region which include India and China. ${ }^{13,14}$ In addition to this, a report published by WHO based on school-based student's health survey, reported that in India $24.6 \%$ of students between the age group 13-15 years old felt so depressed or hopeless almost every day, as a result, they stopped in doing their usual activities ${ }^{15}$ in their daily life. Due to its lot of devastating consequences \& mental health challenges, there has been a long-standing interest in understanding the early risk factors of major or severe depression. However, remarkably we know very little about the prevalence and risk

\footnotetext{
* Corresponding author.

** Corresponding author.

E-mail addresses: tanudas.04321@gmail.com (T. Das), parthadas7852@gmail.com (P. Das), pkkundu.geo@gmail.com (P.K. Kundu), raiganjgeo@gmail.com (T.B. Roy).
} 
factors of adolescents \& young adult's depression in lower-middle-income countries. The depressive disorder may occur in almost all human beings regardless of age, sex, religion, caste, class, human habitation etc. But are more relevant with increasing age from childhood to adulthood and are highly significant with teenagers compared to younger children. ${ }^{14}$ Several professionals have investigated that there has an association between adolescent's depression and household level factors, parental factors and likewise various individual-level factors. Household's economic strengths, parent-adolescents communication, self-esteem, loneliness, gender, age all of these endogenous \& exogenous factors are some strong determinants for adolescent's depression. ${ }^{16,17}$ Furthermore, in terms of socio-demographic factors earlier studies have found that depression is more usual for women, for younger age groups, for those who are residing in nuclear families, belonged to poor socioeconomic status, believed in Muslim religious beliefs, live in an urban environment and to those who are divorced or separated. ${ }^{18-22}$ Witnessing parental physical violence at home has long term adverse consequences on the physiological health of children, apart from this earlier literature asserts that verbal or emotional abuse has also some detrimental effects to increase the likeliness of depressive disorder among adolescents and adults. ${ }^{23-26}$ However, there has been a lot of work on the association between risk factors and depressive disorder among adolescents, younger and older adult boys \& girls all over India but a dearth of work has been identified specifically for the underdeveloped or backward region. Various indicators linked with region's backwardness for example poor income to resource access, poor water supply, unavailability of sanitation, housing, unemployment condition, unhealthy food and its cumulatively effect on parental mental \& physical health and as a result parental factor play the key determinant role for children's mental or emotional health. ${ }^{27-32}$ Bihar is one state of India that comes under Empowered Action Group (EAG) state which is less developed or very poor in socio-economic as well as demographic indicators as compared to other states of India. ${ }^{33}$ In Bihar, as per the report published by the population council of India namely "Understanding the lives of adolescents and young adults (UDAYA) in Bihar, India", pointed out that more than $90 \%$ of boys \& girls displayed symptoms of mildly depressive disorders and nearly $15 \%$ boys and girls reported their moderate to severe depressive disorders. ${ }^{34}$ This current study attempts to bridge the gap of existing literature by finding out the risk factors of moderate to severe depressive disorders among adolescents and young adults from Bihar, a most underdeveloped state of India. This study also tried to identify if there any relationship between depressive disorders and educational outcomes as well as the suicidal outcome of adolescents and young adults in Bihar state.

\section{Data source and methodology}

\subsection{Data}

Data used in this present study was extracted from the Understanding the lives of adolescents and young adults (UDAYA) project survey 2015-2016, which was conducted in two Indian states Bihar and Uttar Pradesh (UP) by population council under the guidance of the Ministry of Health and Family Welfare (MoHFW), Government of India. With the written consent the survey assembled information on respondent's background characteristics, parental relationship, communication, mobility \& decision making, knowledge about gender \& self-efficiency, awareness of sexual \& reproductive matters, mental health indicators, marital life \& marriage process etc. By applying systematic multistage stratified sampling design procedure. Five separate questioners were used to collect information regarding the lives of adolescents and young adults. The first questioner was used for the collection of information on respondent's household characteristics where the questions were asked to the household head or any other elder member of the household. The rest of the four variants of individual-level questioners were distributed gender-wise for two separate age cohorts; these are 10-14 (Adolescents) years \& 15 to 19 (Young adults) years where the questions were asked to the respondent directly by face to face interview. A total 10,433 sample was collected for Bihar and 10,161 for Uttar Pradesh. The survey provides the estimate for the states (Bihar and UP) as a whole as well as for the rural and urban stratum separately of each state. In addition, the project survey was longitudinal and therefore the data was panel data. The first wave (WAVE-1) was conducted in 2015-2016 and the followup survey (WAVE-2) was conducted three years later in 2018-2019.

The used data in this present study is secondary and therefore no ethical approval is required further from any institutional committee or review board after the approval ofthe survey questioner by the population council, New Delhi, Govt. of India. The data is not publicly available but one can assess the data set upon request.

\subsection{Study participants}

This current study has been conducted only on the lives of adolescents and young adults in Bihar state. The representative samples for the state Bihar were 10,433 out of which 1012 were younger boys (aged 10-14 years), 1821 were older boys (aged 15-19 years), 764 were younger girls (aged 10-14 years), 3428 were unmarried older girls (aged 15-19 years) and 3408 were married older girls. After removing all the missing cases from the system for each exposure variable the final study participants for this current study were 7919 out of which 6766 (85.39\%) respondents were mildly depressive symptomatic and 1153 (14.61\%) were moderate to severe depressive asymptotic. Here used all the numbers (Sample Size) are actual numbers but the percentages are a weighted percentage for the overall population representation in Bihar state.

\subsection{Methodology adopted}

In this present study's two statistical methods were performed using STATA version 16.0 (STATA Corp LP, College Station, TX, USA). All the statistical estimates were done on a $5 \% \alpha$-level. Firstly, descriptive statistics were performed to get an overview of selected dependent and independent variables. Secondly, Pearson's Chi-square test statistics is used to check the association of selected independent variables with dependent variables. Lastly, a multivariate logistic regression model was carried out to quantify the association between independent and dependent variables through adjusted odds ratios (AORs) with 95\% Confidence Interval (CI) considering all other cofactors. Before going to the final model this study also checked the model's goodness of fit based on Nagelkerke's $\mathrm{R}^{2}$ and Hosmer \& Lemeshow test. To analyze the relationship between selected dependent (Depressive symptom) variables and two detrimental effect variables (educational outcome and suicidal outcome) of this study were also performed through Pearson's Chisquare goodness of fit test along with observed and expected frequency count. The detail of Dependent and exposure variables has been discussed below.

\subsection{Outcome variable}

Depressive symptom among adolescent and young adult boys and girls (Aged 10 to 19) is the outcome variable for this present study. The respondents were asked about their depressive asymptomatic behaviors only the last 15 days preceding the survey. The questions that were asked are-(a) Over the last 15 days have you had trouble falling asleep? (b) Over the last 15 days, have you been feeling tired or having little energy like not feeling like talking to anyone, doing anything, going anywhere? (c) Over the last 15 days, have you been had a poor appetite? If no, have you been overeating? (d) Over the last 2 weeks, have you had little interest or pleasure in doing things for i.e., Studying, watching TV, cooking, playing? (e) Over the last 15 days, have you been feeling down, depressed or hopeless, thinking that what is happening to me or what will happen in my life and not satisfied with yourself? (f) Over the last 15 
days, have you been feeling bad about yourself- or that you are a failure or have let yourself or your family down? (g) Over the last 15 days, have you been moving or speaking so slowly that other people could have noticed? (h) Over the last 15 days, have you had thoughts that you would be better off dead, or of hurting yourself in some way? (i) Over the last 15 days have you had trouble concentrating on things, such as reading the textbook or paying attention to the teachers in the class, playing, watching TV, cooking? All the above-mentioned questions were asked on a scale ranging from 0 to 3 , where 0 indicates "not at all", 1 indicates "less than once a week", 2 indicates "one week or more" and 3 indicates "nearly every day". Finally, a scale was generated by using "gen" command in STATA 16.0 for each individual by adding all the above-mentioned scores for each respondent and the variable was treated as a count variable for the analytical purpose (Cronbach alpha: 0.87). And lastly, the count variable was recorded to make the variable binary where score ranges between 0 to 9 was considered as mild/ minimal depressive symptom and coded as ' 0 ' and 10 to 27 score was considered as moderate to a severe depressive symptom and coded as ' 1 '. An inter-correlation analysis among the variables based on which the dependent variable is generated was performed to examine how various symptoms of depressive disorders are correlated with each other.

\subsection{Exposure variables}

This present work was carried out based on 10 independent variables out of which 7 variables were treated as the exposure variable and the rest of the 3 were treated as controlling variables or cofactors. The detailed explanations of these variables and their coding (Table 1 ) have been given below-

\section{Results and analysis}

\subsection{Description and distribution of adolescents and young adults based on their background characteristics}

As shown in Table 2, among participants $(7,919)$ estimated in this present study $14.61 \%$ were severely depressive symptomatic. There were nearly $25 \%$ adolescents \& young adults who witnessed that their father beating to their mother evermore. Estimation shows that $43.31 \%$ of adolescents and young adult boys and girls experienced physical violence from their parents. Around $12 \%$ of boys and girls had no freedom to express their personal opinion or view on a particular matter with other elder family members in their family rather than their parent. Near about $40 \%$ respondents were there whose parent does not spend

Table: 1

Explanatory variable used.

\begin{tabular}{|c|c|c|}
\hline $\begin{array}{l}\text { Sl. } \\
\text { No }\end{array}$ & Name the variables & Variable Coding \\
\hline 1. & $\begin{array}{l}\text { Witnessed father ever beating } \\
\text { mother }\end{array}$ & $0=$ No, $1=$ Yes \\
\hline 2. & $\begin{array}{l}\text { Experience physical violence by } \\
\text { parent }\end{array}$ & $0=$ No, $1=$ Yes \\
\hline 3. & $\begin{array}{l}\text { Freedom to express own opinion to } \\
\text { the elder of the family }\end{array}$ & Often $=1$, Some time $=2$, Never $=3$ \\
\hline 4. & $\begin{array}{l}\text { Parent listen to their child's } \\
\text { personal thing if she/he want to } \\
\text { tell }\end{array}$ & $0=$ Yes, $1=$ No \\
\hline 5. & Type of School & $0=$ Government, $1=$ Private \\
\hline 6. & Mass Media Exposure & $0=$ No, $1=$ Yes \\
\hline 7. & Respondent's Mother's Education & $\begin{array}{l}10 \text { Years and above }=1,7-8 \text { Years }= \\
2,8-9 \text { Years }=3 \text {, No education }=4\end{array}$ \\
\hline 8. & Sex of the respondent & Male $=0$, Female $=1$ \\
\hline 9. & Age Groups & $\begin{array}{l}10-12 \text { Years }=1,13-14 \text { Years }=2 \\
15-17 \text { Years }=3,18-19 \text { Years }=4\end{array}$ \\
\hline 10. & $\begin{array}{l}\text { Respondent's Level of Education } \\
\text { (In Year) }\end{array}$ & $\begin{array}{l}1-7 \text { Years }=1,8-9 \text { Years }=2,10 \text { Years } \\
\text { and above }=3\end{array}$ \\
\hline
\end{tabular}

Table: 2

Background characteristics of the respondents $[\mathrm{n}=7919]$.

\begin{tabular}{|c|c|c|}
\hline $\begin{array}{l}\text { Depressive symptom \& its Background } \\
\text { Characteristics }\end{array}$ & $\begin{array}{l}\text { Number } \\
\text { (n) }\end{array}$ & $\begin{array}{l}\text { Weighted } \\
\text { Percentage }\end{array}$ \\
\hline \multicolumn{3}{|l|}{ Nature of Depression } \\
\hline Mild depression & 6766 & 85.39 \\
\hline Severe depression & 1153 & 14.61 \\
\hline \multicolumn{3}{|l|}{ Witnessed father ever beating mother } \\
\hline No & 6072 & 75.25 \\
\hline Yes & 1847 & 24.75 \\
\hline \multicolumn{3}{|l|}{ Experience physical violence by parent } \\
\hline No & 4688 & 56.69 \\
\hline Yes & 3231 & 43.31 \\
\hline \multicolumn{3}{|c|}{ Freedom to express own opinion to the elder of the family } \\
\hline Often & 2176 & 24.98 \\
\hline Sometime & 4899 & 75.02 \\
\hline Never & 844 & 11.98 \\
\hline \multicolumn{3}{|c|}{ Parent listen to their child's personal thing if she/he want to tell } \\
\hline Yes & 4756 & 61.32 \\
\hline No & 3163 & 38.68 \\
\hline \multicolumn{3}{|l|}{ Type of School } \\
\hline Govt. School & 6735 & 90.69 \\
\hline Private School & 1184 & 9.31 \\
\hline \multicolumn{3}{|l|}{ Mass Media Exposure } \\
\hline No & 2858 & 49.57 \\
\hline Yes & 5061 & 50.43 \\
\hline \multicolumn{3}{|l|}{ Mother's Education } \\
\hline 10 Years and Above & 1081 & 08.06 \\
\hline 1-7 Years & 892 & 10.12 \\
\hline 8-9 Years & 653 & 07.43 \\
\hline No Education & 5293 & 74.38 \\
\hline \multicolumn{3}{|l|}{ Control Variable } \\
\hline \multicolumn{3}{|l|}{ Sex } \\
\hline Male & 2408 & 30.53 \\
\hline Female & 5511 & 69.47 \\
\hline \multicolumn{3}{|l|}{ Age Group } \\
\hline $10-12$ Years & 952 & 12.13 \\
\hline 13-14 Years & 606 & 07.51 \\
\hline 15-17 Years & 3871 & 51.07 \\
\hline 18-19 Years & 2490 & 29.30 \\
\hline \multicolumn{3}{|l|}{ Level of Education (In Year) } \\
\hline 1-7 Years & 2790 & 35.23 \\
\hline 8-9 Years & 2841 & 35.88 \\
\hline 10 Years and Above & 2288 & 28.89 \\
\hline
\end{tabular}

any little bit of time to listen to their children's discourse if they want to share. Only $9.31 \%$ of adolescent \& young adult boys \& girls were continuing their study in a self-financed school commonly known as a private school. Out of total, half of the respondents (50.43\%) were familiar with mass media and most of the respondent's mothers (74.38\%) had no formal education. Apart from this, the current study also looked at some control variable such as gender, educational attainment status and age for each respondent to adjust the estimation with some set of variables. Most of the respondents (69.47\%) were female, comes under the age group 15-17 years (51.07\%). Nearly equal distributions were observed for the selected respondents in each category of educational attainment status.

Table 3 Displays the inter-correlations among the variables based on which the outcome variable (Nature of depression) has been created, to determine whether two variables are correlated. Estimations shows that all the 9 variables are significantly and positively correlated with each other but differences has been observed in case of strength of relationship between two variables. The correlation coefficient between trouble in falling asleep and felling tired $[\mathrm{r}=0.63 ; \mathrm{P}=<0.01] /$ poor appetite $[\mathrm{r}$ $=0.56 ; \mathrm{P}=<0.01] /$ felling depressed $[\mathrm{r}=0.51 ; \mathrm{P}=<0.01]$ are largely correlated. Similarly, a large, significant \& positive correlation coefficient were also identified between poor appetite and little interest in doing anything $[\mathrm{r}=0.51 ; \mathrm{P}=<0.01] /$ felling tired and poor appetite $[\mathrm{r}$ $=0.55 ; \mathrm{P}=<0.01] /$ felling tired and little interest and doing anything $[\mathrm{r}$ $=0.59 ; \mathrm{P}=<0.01] /$ poor appetite and little interest in doing anything $[\mathrm{r}=0.51 ; \mathrm{P}=<0.01] /$ feeling depressed and feeling bad about own self $[\mathrm{r}=0.53 ; \mathrm{P}=<0.01] /$ feeling bad about own self and abnormality in 
Table: 3

Correlation matrix among indicator variables.

\begin{tabular}{|c|c|c|c|c|c|c|c|c|c|}
\hline \multirow[t]{2}{*}{ Indicator Variables } & \multicolumn{9}{|c|}{ Inter-correlations among the variables } \\
\hline & (a) & (b) & (c) & (d) & (e) & (f) & (g) & (h) & (i) \\
\hline Trouble in falling asleep $(\boldsymbol{a})$ & 1 & & & & & & & & \\
\hline Felling tired/have little energy (b) & $\begin{array}{l}0.627 \\
(0.000)\end{array}$ & 1 & & & & & & & \\
\hline Poor appetite (c) & $\begin{array}{l}0.556 \\
(0.000)\end{array}$ & $\begin{array}{l}0.553 \\
(0.000)\end{array}$ & 1 & & & & & & \\
\hline Little interest in doing anything $(d)$ & $\begin{array}{l}0.424 \\
(0.000)\end{array}$ & $\begin{array}{l}0.594 \\
(0.000)\end{array}$ & $\begin{array}{l}0.506 \\
(0.000)\end{array}$ & 1 & & & & & \\
\hline Felling depressed/hopeless ( $\boldsymbol{e}$ ) & $\begin{array}{l}0.510 \\
(0.000)\end{array}$ & $\begin{array}{l}0.466 \\
(0.000)\end{array}$ & $\begin{array}{l}0.458 \\
(0.000)\end{array}$ & $\begin{array}{l}0.794 \\
(0.000)\end{array}$ & 1 & & & & \\
\hline Felling bad about own $\operatorname{self}(f)$ & $\begin{array}{l}0.427 \\
(0.000)\end{array}$ & $\begin{array}{l}0.458 \\
(0.000)\end{array}$ & $\begin{array}{l}0.445 \\
(0.000)\end{array}$ & $\begin{array}{l}0.523 \\
(0.000)\end{array}$ & $\begin{array}{l}0.527 \\
(0.000)\end{array}$ & 1 & & & \\
\hline $\begin{array}{l}\text { Abnormality in natural speaking } \\
(\mathrm{g})\end{array}$ & $\begin{array}{l}0.342 \\
(0.000)\end{array}$ & $\begin{array}{l}0.352 \\
(0.000)\end{array}$ & $\begin{array}{l}0.349 \\
(0.000)\end{array}$ & $\begin{array}{l}0.404 \\
(0.000)\end{array}$ & $\begin{array}{l}0.422 \\
(0.000)\end{array}$ & $\begin{array}{l}0.604 \\
(0.000)\end{array}$ & 1 & & \\
\hline Abnormality in thought $(\boldsymbol{h})$ & $\begin{array}{l}0.364 \\
(0.000)\end{array}$ & $\begin{array}{l}0.371 \\
(0.000)\end{array}$ & $\begin{array}{l}0.368 \\
(0.000)\end{array}$ & $\begin{array}{l}0.411 \\
(0.000)\end{array}$ & $\begin{array}{l}0.445 \\
(0.000)\end{array}$ & $\begin{array}{l}0.521 \\
(0.000)\end{array}$ & $\begin{array}{l}0.561 \\
(0.000)\end{array}$ & 1 & \\
\hline Felling trouble in concentration (i) & $\begin{array}{l}0.265 \\
(0.000)\end{array}$ & $\begin{array}{l}0.259 \\
(0.000)\end{array}$ & $\begin{array}{l}0.249 \\
(0.000)\end{array}$ & $\begin{array}{l}0.255 \\
(0.000)\end{array}$ & $\begin{array}{l}0.291 \\
(0.000)\end{array}$ & $\begin{array}{l}0.394 \\
(0.000)\end{array}$ & $\begin{array}{l}0.387 \\
(0.000)\end{array}$ & $\begin{array}{l}0.390 \\
(0.000)\end{array}$ & 1 \\
\hline
\end{tabular}

Note: All Correlation coefficients are significant at the 0.01 level (2-tailed).

thought $[\mathrm{r}=0.52 ; \mathrm{P}=<0.01] /$ abnormality in natural speaking and abnormality in thought $[\mathrm{r}=0.56 ; \mathrm{P}=<0.01]$ etc. A Very large, positive and significant correlation coefficients were observed between little interest in doing anything and feeling depressed $[\mathrm{r}=0.79 ; \mathrm{P}=<0.01]$ / feeling bad about own-self and abnormality in natural speaking $[\mathrm{r}=$ $0.60 ; \mathrm{P}=<0.01]$. From this analysis this study may concluded that there were consistency among the variables and inter-relationship among the variables based on which the outcome variable (Nature of depression) has been generated.

\subsection{Screening of depressive symptoms for adolescents and young adult boys and girls and it's association with risk factors}

Table 4 represents the bivariate percentage distribution along with the test of the association through the chi-square test between dependent and selected independent variables. All most all the independent variables are significantly associated with the dependent variable at level $\mathrm{P}<0.05$. Among all adolescents and young adult boys and girls who were witnessed domestic violence (violence between father \& mother) at home, $20.25 \%$ were reported moderate to severe depressive symptoms [Chi square 62.67; $\mathrm{P}<0.001$ ]. The prevalence of severe depressive symptoms was nearly identical for those respondents who were experienced (14.89\%) as well as not experienced (14.33\%) physical violence by their parents [Chi square 81.83; $\mathrm{P}<0.001$ ]. To some extent, the severe depressive symptom was higher (16.47\%) among those boys \& girls who had no freedom to express their personal opinion on any matter to the elder member of this family [Chi square 68.89; $\mathrm{P}=$ $0.001]$. Interestingly, the severe depressive symptom was found more $(31.25 \%)$ for those respondents who want to share their things with the parent but the parent had no time to listen to their descendants [Chi square 56.27; $\mathrm{P}=0.001$ ]. Estimation shows that the proportions of severe depression symptoms were slightly higher (15.03\%) among those adolescents \& young adults who were studied at govt. school [Chi square 84.31; $\mathrm{P}=0.001$ ]. Similarly, the proportions of severe depression symptoms were comparatively more $(15.96 \%)$ for those adolescents and young adults who were not a mass media exposure [Chi square 71.82; $\mathrm{P}$ $=0.001]$. A significant association has been observed between respondent's mother's education \& their depressive symptoms [Chi square 68.65; $\mathrm{P}=0.001]$. Moreover, the respondents whose mother had no formal education $(14.98 \%)$ or had very minimum education $(15.47 \%)$ were mostly surviving with severe depression. All the control variables i. e. respondent's sex, age, and educational attainment status are significantly associated with their depressive symptom. The prevalence of severe depressive symptoms were higher among those respondents who
Table: 4

Test of association between depressive symptom and background characteristics for adolescents and young adult boys and girls.

\begin{tabular}{|c|c|c|c|c|}
\hline \multirow{2}{*}{$\begin{array}{l}\text { Background } \\
\text { Characteristics }\end{array}$} & \multicolumn{4}{|c|}{ Percentage Distribution \& Measures of Association } \\
\hline & $\begin{array}{l}\text { Minimal to Mild } \\
\text { Symptoms }\end{array}$ & $\begin{array}{l}\text { Moderate to } \\
\text { Severe Symptom }\end{array}$ & $\begin{array}{l}\text { Chi-squire } \\
\text { Value }\end{array}$ & $\begin{array}{l}\text { P- } \\
\text { Value }\end{array}$ \\
\hline \multicolumn{5}{|c|}{ Witnessed father ever beating mother } \\
\hline No & 87.17 & 12.83 & \multirow[t]{2}{*}{62.67} & \multirow[t]{2}{*}{0.000} \\
\hline Yes & 79.75 & 20.25 & & \\
\hline \multicolumn{5}{|c|}{ Experience physical violence by parent } \\
\hline No & 85.67 & 14.33 & \multirow[t]{2}{*}{81.83} & \multirow[t]{2}{*}{0.000} \\
\hline Yes & 85.11 & 14.89 & & \\
\hline \multicolumn{5}{|c|}{ Freedom to express own opinion to the elder of the family } \\
\hline Often & 87.68 & 12.32 & \multirow[t]{3}{*}{68.89} & \multirow[t]{3}{*}{0.001} \\
\hline Sometime & 84.77 & 15.23 & & \\
\hline Never & 83.53 & 16.47 & & \\
\hline \multicolumn{5}{|c|}{ Parent listen to their child's personal thing if she/he want to tell } \\
\hline Yes & 85.18 & 14.82 & \multirow[t]{2}{*}{56.27} & \multirow[t]{2}{*}{0.000} \\
\hline No & 68.75 & 31.25 & & \\
\hline \multicolumn{5}{|l|}{ Type of School } \\
\hline Govt. School & 84.97 & 15.03 & \multirow[t]{2}{*}{84.31} & \multirow[t]{2}{*}{0.001} \\
\hline Private School & 88.09 & 11.91 & & \\
\hline \multicolumn{5}{|c|}{ Mass Media Exposure } \\
\hline No & 84.04 & 15.96 & \multirow[t]{2}{*}{71.82} & \multirow[t]{2}{*}{0.001} \\
\hline Yes & 86.23 & 13.77 & & \\
\hline \multicolumn{5}{|c|}{ Mother's Education } \\
\hline $\begin{array}{l}10 \text { Years and } \\
\text { Above }\end{array}$ & 87.51 & 12.49 & \multirow[t]{6}{*}{68.65} & \multirow[t]{4}{*}{0.001} \\
\hline 1-7 Years & 84.53 & 15.47 & & \\
\hline 8-9 Years & 86.68 & 13.32 & & \\
\hline No Education & 85.02 & 14.98 & & \\
\hline \multicolumn{4}{|c|}{ Control Variable } & \\
\hline \multicolumn{4}{|l|}{ Sex } & \\
\hline Male & 93.06 & 06.94 & \multirow[t]{2}{*}{161.7} & \multirow[t]{2}{*}{0.000} \\
\hline Female & 82.11 & 17.89 & & \\
\hline Age Groups & & & & \\
\hline $10-12$ Years & 95.8 & 04.20 & 175.00 & 0.001 \\
\hline 13-14 Years & 93.4 & 06.60 & & \\
\hline 15-17 Years & 85.22 & 14.78 & & \\
\hline 18-19 Years & 79.88 & 20.05 & & \\
\hline Level of Educa & In Year) & & & \\
\hline 1-7 Years & 89.43 & 10.57 & 57.69 & 0.000 \\
\hline 8-9 Years & 83.56 & 16.44 & & \\
\hline $\begin{array}{l}10 \text { Years and } \\
\text { Above }\end{array}$ & 82.91 & 17.09 & & \\
\hline
\end{tabular}


were female (17.89\%), continuing their education with more than 10 years $(17.09 \%)$, lying between the age group 15-17 years (14.78\%).

\subsection{Estimation of adjusted odd ratios for moderate to severe depressive disorders among adolescent and young adult boys \& girls}

Table 5 depicts a multivariate logistic regression model for those adolescent and young adult boys and girls who were reported moderate to severe depressive symptoms through their behavior in the last 15 days preceding the survey. Estimation showed that the odds of severe depressive symptoms were significantly higher [AOR: 1.73; $\mathrm{P}<0.05$; 95\% CI: 1.50-1.97] among those boys \& girls who witnessed domestic violence (Violence between father and mother) at home in comparison to those who have not witnessed this kind violence offence at home. Compare with the reference category, the adolescent and young adult boys and girls who were physically violated by their parents were significantly more likely [AOR: 1.59; P $<0.05$; 95\% CI: $1.48-1.71$ ] to experience severe depression. The likelihood of severe depressive symptoms was significantly $41 \%$ higher [AOR: 1.41 ; P $<0.05$; $95 \%$ CI: 1.12-1.57] among those respondents who had no freedom to express their opinion to the elder member of their family, in contrary to this the odds was 17\% lower [AOR: 0.83; P < 0.05; 95\% CI: 0.69-1.12] for those boys \& girls who had a permit to express their opinion sometimes to the elder family member in compare to the reference category. The tendency of falling in severe depressive symptoms was 1.18 times higher [AOR: 1.18; P < 0.05; 95\% CI: 0.96-1.31] among those boys and girls whose parents hardly spend any little bit of time to listen to their child if he/she want to share his/her problem with their parent. The likelihood of severe depressive symptoms was 31\% higher [AOR: 1.31; P $<0.05 ; 95 \%$ CI: 1.11-1.47] among those adolescents \& young adults who were continuing their education from a private school (Non-Govt.) rather than any govt. the school even after controlling all the control variables. Furthermore, estimation showed $16 \%$ lesser odds [AOR: 0.84; $\mathrm{P}<0.05$; 95\% CI: 0.75-0.94] of severe depression for those respondents who were mass media exposure compared to non-exposure. Lastly, the boys \& girls whose mother had no formal education were 1.23 times more likely to fall into severe depression compared to those whose mother had more than 10 years of formal education.

Table 5

Logistic regression, estimating the odds for moderate to severe depressive disorder among adolescents and young adults.

\begin{tabular}{|c|c|c|c|}
\hline Background Characteristics & AOR & $\mathrm{P}>|\mathrm{Z}|$ & $95 \% \mathrm{CI}$ \\
\hline \multicolumn{4}{|c|}{ Witnessed father ever beating mother } \\
\hline No & Ref. & & \\
\hline Yes & 1.73 & 0.001 & [1.50-1.97] \\
\hline \multicolumn{4}{|c|}{ Experience physical violence by parent } \\
\hline No & Ref. & & \\
\hline Yes & 1.59 & 0.001 & [1.48-1.71] \\
\hline \multicolumn{4}{|c|}{ Freedom to express own opinion to the elder of the family } \\
\hline Often & Ref. & & \\
\hline Sometime & 0.83 & 0.001 & [0.69-1.12] \\
\hline Never & 1.41 & 0.003 & [1.12-1.57] \\
\hline \multicolumn{4}{|c|}{ Parent listen to their child's personal thing if she/he want to tell } \\
\hline Yes & Ref. & & \\
\hline No & 1.18 & 0.031 & [0.96-1.31] \\
\hline \multicolumn{4}{|l|}{ Type of School } \\
\hline Govt. School & Ref. & & \\
\hline Private School & 1.31 & 0.000 & [1.11-1.47] \\
\hline \multicolumn{4}{|l|}{ Mass Media Exposure } \\
\hline No & Ref. & & \\
\hline Yes & 0.84 & 0.004 & [0.74-0.95] \\
\hline \multicolumn{4}{|l|}{ Mother's Education } \\
\hline 10 Years and Above & Ref. & & \\
\hline 1-7 Years & 1.28 & 0.071 & [0.99-1.65] \\
\hline 8-9 Years & 1.07 & 0.000 & [0.80-1.11] \\
\hline No Education & 1.23 & 0.001 & [1.09-1.29] \\
\hline
\end{tabular}

Note: AOR -Adjusted Odd Ratio; CI- Confidence Interval; Ref. - Reference Category.
3.4. Test of association between depression symptom among adolescents \& young adults and their undesirable educational outcome \& suicidal attempt

Table 6 Using a Chi-square test, this study has tried to explore if there is an association between respondent's educational outcome and depressive symptoms as well as their suicidal attempt and depressive symptom. Estimation showed that among adolescents and young adults with mild and severe depressive disorder a total of 30 boys \& girls were performed very poorly in their last year academic result because of their severe depressive nature, but the study would expect to have only 18.5 boys $\&$ girls by chance. By contrast, 346 respondents have done average performance but the study would expect 358 . Similarly, a little difference was also found in the case of good performance in the case of last year academic result. So, the result indicates that there is a significant association [Pearson chi2 (2) $=8.6522 \mathrm{Pr}=0.013$ ] between educational outcome and depressive symptoms of adolescents and young adults.

As earlier said this study also tried to detect the association between respondent's suicidal attempt and their depressive nature in the last year preceding the survey and the study found that a total of 163 boys and girls attempt last year suicide due to their severe depressive nature but the study would expect only for 37.7 boys and girls. Similarly, the observed \& expected frequencies for not taking suicidal attempts due to severe depression were $948 \& 1071.8$. Estimation indicates that there is a significant association [Pearson chi2 $(2)=513.38 \mathrm{Pr}=0.000$ ] between adolescents and young adults suicidal attempts and their depressive nature.

\section{Discussion}

Persistent feeling of sadness, loss of interest in doing anything is characterized by a severe or major depressive disorder that can lead to a range of behavioural and physical symptoms. These may include changes in sleeping pattern, appetite, energy level, daily behaviour or

Table: 6

Test of association between Depressive Symptom among Adolescents \& Young Adults and their Undesirable Educational outcome \& Suicidal attempt.

\begin{tabular}{|c|c|c|c|c|c|}
\hline \multicolumn{2}{|c|}{$\begin{array}{l}\text { Undesired Educational \& } \\
\text { Suicidal Outcome }\end{array}$} & \multicolumn{4}{|c|}{$\begin{array}{l}\text { Depression Symptom among adolescents \& Young } \\
\text { Adults }\end{array}$} \\
\hline & & $\begin{array}{l}\text { Minimal to } \\
\text { Mild } \\
\text { Symptoms }\end{array}$ & $\begin{array}{l}\text { Moderate to } \\
\text { Severe } \\
\text { Symptom }\end{array}$ & $\begin{array}{l}\text { Chi- } \\
\text { Square } \\
\text { Value }\end{array}$ & $\begin{array}{l}\mathrm{P}- \\
\text { Value }\end{array}$ \\
\hline \multicolumn{6}{|c|}{ Performance in class in last academic year $[\mathrm{n}=5336]$} \\
\hline $\begin{array}{c}\text { Observed } \\
\text { Count }\end{array}$ & Very Poor & 119 & 30 & 8.65 & 0.013 \\
\hline $\begin{array}{l}\text { Expected } \\
\text { Count }\end{array}$ & & 130.5 & 18.5 & & \\
\hline $\begin{array}{l}\text { Observed } \\
\text { Count }\end{array}$ & Average & 2540 & 346 & & \\
\hline $\begin{array}{l}\text { Expected } \\
\text { Count }\end{array}$ & & 2528 & 358 & & \\
\hline $\begin{array}{l}\text { Observed } \\
\text { Count }\end{array}$ & Well & 2015 & 286 & & \\
\hline $\begin{array}{c}\text { Expected } \\
\text { Count }\end{array}$ & & 2015.5 & 285.5 & & \\
\hline \multicolumn{6}{|c|}{ Attempt to Suicide in last one Year $[n=6967]$} \\
\hline $\begin{array}{c}\text { Observed } \\
\text { Count }\end{array}$ & Yes & 73 & 163 & 513.38 & 0.000 \\
\hline $\begin{array}{l}\text { Expected } \\
\text { Count }\end{array}$ & & 198.3 & 37.7 & & \\
\hline $\begin{array}{c}\text { Observed } \\
\text { Count }\end{array}$ & No & 5761 & 948 & & \\
\hline $\begin{array}{l}\text { Expected } \\
\text { Count }\end{array}$ & & 5637.2 & 1071.8 & & \\
\hline $\begin{array}{l}\text { Observed } \\
\text { Count }\end{array}$ & $\begin{array}{l}\text { Don't } \\
\text { want to }\end{array}$ & 20 & 2 & & \\
\hline $\begin{array}{l}\text { Expected } \\
\text { Count }\end{array}$ & share & 18.5 & 3.5 & & \\
\hline
\end{tabular}


self-esteem etc. ${ }^{35-37}$ This current study has ascertained some triggering factors affecting adolescents and young adult's depressive disorders based on a state-level project survey data verse (UDAYA). The study revealed that depressive disorders are more common among those adolescents and young adults who were witnessing parental violence at home and the deduction is consistent with various previous findings. ${ }^{38-41}$ Besides this, some researchers go beyond this current study and identified the immense impact of domestic violence on the rest of the adult's lives after early young life-course for example adolescents or young adults who witness violence between parents may also be at greater risk of being violent and to be violated in their future relationship. ${ }^{42,43}$ Furthermore, other important findings revealed that the likeliness of moderate to severe depressive disorder is higher among those adolescents or young adults who often used to be physically punished by their parents, had no permission to disclose their opinion to the other elder member of that family and to those whose parents neglect their child to hear personal things if they want to share, studied at private school and had no educational attainment or very less. Our generalization is also identical with several earlier generalizations which have been done nationally as well as international background. ${ }^{5,44-46}$ Experience of parental negligence (Not listening to their child) not only put adolescents and young adults at risk for immediate adverse consequences such as poor academic performance and increased emotional distress but may also long term serious health outcomes such as delinquency, low self-esteem, aggression, anxiety, substance abuse and depression etc. ${ }^{47,48}$ In general academic stress is higher in self-financed schools commonly known as public schools compared to govt. sponsored school and such stress may arise due to heavy school schedules, overburden, unrealistic expectation and extreme demands of parents and teachers. Furthermore, academic stress is recognized as a significant risk factor for depressive disorder and suicidal behaviour. ${ }^{49,50}$ The current estimation apprised that the probability of depressive disorder is lower among those boys and girls who are mass media exposure but the result is not always consistent and analogous with all other findings because of its dichotomized corporeity. ${ }^{51,52}$ Certain previous findings have drawn the inference that television exposure or any kind of media exposure are associated with increased odds of depressive symptoms and contrary to this some findings also confirmed the depreciatory illation. Usually media content may lead to depression more baldly. Cultural messages, value behaviour, positive and negative news attribution, transmitted through media may implicate on human being behaviours related to mental health such as eating disorder and aggressive behaviour and finally fall into depressive disorder. Likewise, it should be noted that exposure to certain media content such as movies, songs, drama, educational counseling, transport \& travel shot, cooking may etc. Might help to reduce the likelihood of developing depression. All of these study findings suggest an important pathway for future study and interventions to reduce the massive toll of depressive disorder in adolescents and young adults not only for this study are but also for the national as well as the international sphere.

\section{Conclusion}

Depression is a most common human behaviour and very fundamental for childhood and adulthood ages. This study suggests that if parents or any other elder member noticed their child a depressive mood they need to take some decrement steps rather than sit back and take a wait-and-see approach. This current study allows the parents, school teachers, elder members of the family and guardians to know why adolescents or young adults fall into depression and how often it is associated with educational \& suicidal outcomes. This study also helps the guardian to change societal so-called behaviour by remembering not to do any violence in front of their child, to educate himself/herself more, by spending time with their child as more as possible etc. Finally, this study wants to highlight that to minimize depressive disorder in adolescents and young adults it is an urgent need to shifting the depression reducing program from a universal basis to family-based prevention and intervention programmes.

\section{Ethical statement}

This material has not been published in whole or in part elsewhere. The manuscript is not currently being considered for publication in another journal.

All the authors have been personally and actively involved in substantive work leading to the manuscript and will hold themselves jointly and individually responsible for its content.

\section{Funding}

This research received no specific grant from any funding agency, commercial entity or any profit and non-profit organization.

\section{Author's contribution}

Conception and design of study: Tanu Das, Tamal Basu Roy, Partha Das, Prabir Kumar Kundu.

Acquisition of data, methods: Tanu Das.

Analysis of data: Tanu Das.

Drafting the manuscript: Tanu Das, Tamal Basu Roy, Partha Das, Prabir Kumar Kundu.

\section{Data availability}

Data are publicly available and one can access upon request.

\section{Consent to participate}

The used data in this present study is secondary in nature and therefore no ethical approval is required further from any institutional committee or review board after the approval of survey questioner by population council, New Delhi, Govt. of India. The data is not publicly available but one can assess the data set upon request.

\section{Declaration of competing interest}

The authors declare that they have no known competing financial interests or personal relationships that could have appeared to influence the work reported in this paper.

\section{Acknowledgment}

None.

\section{References}

1 Clark C, Rodgers B, Caldwell T, Power C, Stansfeld S. Childhood and adulthood psychological ill health as predictors of midlife affective and anxiety disorders: the 1958 British Birth Cohort. Arch Gen Psychiatr. 2007 Jun 1;64(6):668-678.

2 Lewinsohn PM, Rohde P, Seeley JR. Major depressive disorder in older adolescents: prevalence, risk factors, and clinical implications. Clin Psychol Rev. 1998 Nov 1;18 (7):765-794.

3 Fletcher JM. Adolescent depression and educational attainment: results using sibling fixed effects. Health Econ. $2010 \mathrm{Jul} ; 19(7): 855-871$.

4 Hasler G, Pine DS, Kleinbaum DG, et al. Depressive symptoms during childhood and adult obesity: the Zurich Cohort Study. Mol Psychiatr. 2005 Sep;10(9):842-850.

5 Fergusson DM, et Woodward LJ. Mental health, educational, and social role outcomes of adolescents with depression. Arch Gen Psychiatr. 2002;59:225-231.

6 Blazer DG, Hybels CF, Fillenbaum GG, Pieper CF. Predictors of antidepressant use among older adults: have they changed over time? Am J Psychiatr. 2005 Apr 1;162 (4):705-710.

7 Vijayakumar S, Malaikozhundan B, Gobi N, Vaseeharan B, Murthy C. Protective effects of chitosan against the hazardous effects of zinc oxide nanoparticle in freshwater crustaceans Ceriodaphniacornuta and Moinamicrura. Limnologica. 2016 Nov 1;61:44-51.

8 Zubrick SR, Hafekost J, Johnson SE, Sawyer MG, Patton G, Lawrence D. The continuity and duration of depression and its relationship to non-suicidal self-harm 
and suicidal ideation and behavior in adolescents 12-17. J Affect Disord. 2017 Oct 1; 220:49-56.

9 Bardone AM, Moffitt TE, Caspi A, Dickson N, Silva PA. Adult mental health and social outcomes of adolescent girls with depression and conduct disorder. Dev Psychopathol. 1996;8(4):811-829.

10 Ryan ND. Treatment of depression in children and adolescents. Lancet. 2005 Sep 10; 366(9489):933-940.

11 Wakefield AJ, Murch SH, Anthony A, et al. RETRACTED: ileal-lymphoid-nodular hyperplasia, non-specific colitis, and pervasive developmental disorder in children. Lancet. 1998 Feb 28;351(9103):637-641.

12 Mathers CD, Loncar D. PLoS Med. 2006;3(11):e442.

13 World Health Organization. Mental Health Status of Adolescents in South-East Asia: Evidence for Action.

14 Grover S, Raju VV, Sharma A, Shah R. Depression in children and adolescents: a review of Indian studies. Indian J Psychol Med. 2019 May;41(3):216-227.

15 Depression WH. Other Common Mental Disorders: Global Health Estimates. Geneva: World Health Organization; 2017 Feb:1-24.

16 Robertson JF, Simons RL. Family factors, self-esteem, and adolescent depression. J Marriage Fam. 1989 Feb 1:125-138.

17 Brage D, Meredith WM, Woodward J. Correlates of loneliness among Midwestern adolescents. Adolescence. 1993 Sep 22;28(111):685-694.

18 Poongothai S, Pradeepa R, Ganesan A, Mohan V. Prevalence of depression in a large urban South Indian population - the Chennai Urban Rural Epidemiology study (CURES-70). PLoS One. 2009 Sep 28;4(9), e7185.

19 Ganguli HC. Epidemiological findings on prevalence of mental disorders in India. Indian J Psychiatr. 2000 Jan;42(1):14.

20 Ponnudurai R, Somasundaram O, Balakrishnan S, Srinivasan N. Depression - a study of 80 cases. Indian J Psychiatr. 1981 Jul;23(3):256.

21 Nandi DN, Banerjee G, Boral GC, Ganguli H, Ghosh A, Sarkar S. Socio-economic status and prevalence of mental disorders in certain rural communities in India. Acta Psychiatr Scand. 1979 Mar;59(3):276-293.

22 Mohandas E. Roadmap to Indian psychiatry. Indian J Psychiatr. 2009 Jul;51(3):173.

23 Devries KM, Mak JY, Bacchus LJ, et al. Intimate partner violence and incident depressive symptoms and suicide attempts: a systematic review of longitudinal studies. PLoS Med. 2013 May 7;10(5), e1001439.

24 Jones L, Hughes M, Unterstaller U. Post-traumatic stress disorder (PTSD) in victims of domestic violence: a review of the research. Trauma Violence Abuse. 2001 Apr;2(2): 99-119.

25 Coker AL, Davis KE, Arias I, et al. Physical and mental health effects of intimate partner violence for men and women. Am J Prev Med. 2002 Nov 1;23(4):260-268.

26 Romito P, MolzanTuran J, De Marchi M. The impact of current and past interpersonal violence on women's mental health. Soc Sci Med. 2005;60(8):1717-1727. https:// doi.org/10.1016/j.socscimed.2004.08.026, 1982.

27 Elliott I. Poverty and Mental Health: A Review to Inform the Joseph Rowntree Foundation's Anti-poverty Strategy. London: Mental Health Foundation; 2016 Jun: $1-10$.

28 Saraceno B, Barbui C. Poverty and mental illness. Can J Psychiatr. 1997 Apr;42(3): 285-290.

29 Santiago CD, Kaltman S, Miranda J. Poverty and mental health: how do low-income adults and children fare in psychotherapy? J Clin Psychol. 2013 Feb;69(2):115-126.

30 Kuruvilla A, Jacob KS. Poverty, social stress \& mental health. Indian J Med Res. 2007 Oct $1 ; 126(4): 273$

31 McLeod JD, Shanahan MJ. Poverty, parenting, and children's mental health. Am Socio Rev. 1993 Jun 1:351-366.

32 Assis SG, Avanci JQ, Oliveira RD. Socioeconomic inequalities and child mental health. Rev Saude Publica. 2009;43:92-100.
33 Singh NK, Singh BP, Yadava KN, Singh BP. A study of socio demographic condition of North eastern Bihar. Recent Res Sci Technol. 2013 Jun 27;5(4).

34 Santhya KG, Acharya R, Pandey N, et al. Understanding the Lives of Adolescents and Young Adults (UDAYA) in Bihar, (India).

35 Yorbik O, Birmaher B, Axelson D, Williamson DE, Ryan ND. Clinical characteristics of depressive symptoms in children and adolescents with major depressive disorder. J Clin Psychiatr. 2004 Dec 1;65(12):1654-1659.

36 Mendlewicz J. Sleep disturbances: core symptoms of major depressive disorder rather than associated or comorbid disorders. World J Biol Psychiatr. 2009 Jan 1;10 (4):269-275.

37 Fogel J, Eaton WW, Ford DE. Minor depression as a predictor of the first onset of major depressive disorder over a 15-year follow-up. Acta Psychiatr Scand. 2006 Jan; 113(1):36-43.

38 Reynolds MW, Wallace J, Hill TF, Weist MD, Nabors LA. The relationship between gender, depression, and self-esteem in children who have witnessed domestic violence. Child Abuse Negl. 2001 Sep 1;25(9):1201-1206.

39 Huth-Bocks AC, Levendosky AA, Semel MA. The direct and indirect effects of domestic violence on young children's intellectual functioning. J Fam Violence. 2001 Sep;16(3):269-290.

40 Patel R, Gupte SS, Srivastava S, et al. Experience of gender-based violence and its effect on depressive symptoms among Indian adolescent girls: evidence from UDAYA survey. PLoS One. 2021 Mar 25;16(3), e0248396.

41 Evans SDC, DiLillo D. Exposure to domestic violence: a meta-analysis of child and adolescent outcomes. Aggress Violent Behav. 2008;13(2):131-140.

42 Maker AH, Kemmelmeier M, Peterson C. Long-term psychological consequences in women of witnessing parental physical conflict and experiencing abuse in childhood. J Interpers Violence. 1998 Oct;13(5):574-589.

43 Kernsmith P. Gender differences in the impact of family of origin violence on perpetrators of domestic violence. J Fam Violence. 2006 Feb 1;21(2):163-171.

44 Maughan B, Collishaw S, Stringaris A. Depression in childhood and adolescence. Journal of the Canadian Academy of Child and Adolescent Psychiatry = Journal de l'Academiecanadienne de psychiatrie de l'enfant et de l'adolescent. 2013;22(1):35-40.

45 Huh HJ, Kim KH, Lee HK, Chae JH. The relationship between childhood trauma and the severity of adulthood depression and anxiety symptoms in a clinical sample: the mediating role of cognitive emotion regulation strategies. J Affect Disord. 2017 Apr 15;213:44-50.

46 Aronen ET, Soininen M. Childhood depressive symptoms predict psychiatric problems in young adults. Can J Psychiatr. 2000 Jun;45(5):465-470.

47 Infurna MR, Reichl C, Parzer P, Schimmenti A, Bifulco A, Kaess M. Associations between depression and specific childhood experiences of abuse and neglect: a metaanalysis. J Affect Disord. 2016 Jan 15;190:47-55.

48 Brown J, Cohen P, Johnson JG, Smailes EM. Childhood abuse and neglect: specificity of effects on adolescent and young adult depression and suicidality. J Am Acad Child Adolesc Psychiatry. 1999 Dec 1;38(12):1490-1496.

49 Ang RP, Huan VS. Relationship between academic stress and suicidal ideation: testing for depression as a mediator using multiple regression. Child Psychiatr Hum Dev. 2006 Dec;37(2):133-143.

50 Zhang WJ, Yan C, Shum D, Deng CP. Responses to academic stress mediate the association between sleep difficulties and depressive/anxiety symptoms in Chinese adolescents. J Affect Disord. 2020 Feb 15;263:89-98.

51 Primack BA, Swanier B, Georgiopoulos AM, Land SR, Fine MJ. Association between media use in adolescence and depression in young adulthood: a longitudinal study. Arch Gen Psychiatr. 2009 Feb 1;66(2):181-188.

52 Thomée S, Härenstam A, Hagberg M. Mobile phone use and stress, sleep disturbances, and symptoms of depression among young adults-a prospective cohort study. BMC Publ Health. 2011 Dec;11(1), 1-1. 